\title{
Wastewater treatment plant effluent as a source of microplastics: review of the fate, chemical interactions and potential risks to aquatic organisms
}

\author{
Shima Ziajahromi, Peta A. Neale and Frederic D. L. Leusch
}

\begin{abstract}
Wastewater treatment plant (WWTP) effluent has been identified as a potential source of microplastics in the aquatic environment. Microplastics have recently been detected in wastewater effluent in Western Europe, Russia and the US. As there are only a handful of studies on microplastics in wastewater, it is difficult to accurately determine the contribution of wastewater effluent as a source of microplastics. However, even the small amounts of microplastics detected in wastewater effluent may be a remarkable source given the large volumes of wastewater treatment effluent discharged to the aquatic environment annually. Further, There is strong evidence that microplastics can interact with wastewater-associated contaminants, which has the potential to transport chemicals to aquatic organisms after exposure to contaminated microplastics. In this review we apply lessons learned from the literature on microplastics in the aquatic environment and knowledge on current wastewater treatment technologies with the aim of identifying the research gaps in terms of (i) the fate of microplastics in WWTPS, (ii) the potential interaction of wastewater-based microplastics with trace organic contaminants and metals, and (iii) the risk for aquatic organisms. Key words | fate, microplastics, removal, risk, sorption capacity, wastewater
\end{abstract}

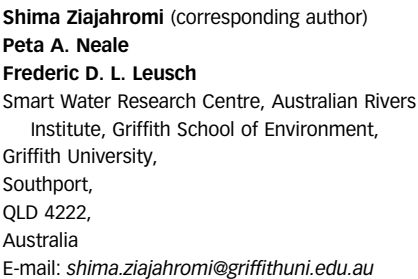

\section{ABBREVIATIONS USED}

DDT $=$ Dichlorodiphenyltrichloroethane; FT-IR $=$ Fourier Transform Infrared LOAEC $=$ lowest observable adverse effect concentration; PAH $=$ Polycyclic Aromatic Hydrocarbon; $\mathrm{PBDE}=$ Polybrominated Diphenyl Ether; $\mathrm{PCB}=$ Polychlorinated Biphenyl; PVC = Polyvinyl Chloride; TrOC $=$ Trace Organic Contaminants; UPVC $=$ Unplasticized Polyvinyl Chloride; WWTP $=$ Wastewater Treatment Plant; $\mathrm{K}_{\mathrm{PE}}-\mathrm{W}=$ Polyethylene-water partition coefficient; $\mathrm{K}_{\mathrm{OW}}=$ Octanol-water partition coefficient.

\section{INTRODUCTION}

The occurrence of plastic debris as a widespread pollutant has been reported in various aquatic environments, including rivers, lakes, estuaries, coastlines and marine ecosystems, and represents an increasing environmental concern (Eerkes-Medrano et al. 20I5).

Currently, the polymers that contribute to $90 \%$ of plastic products are (low-density and high-density) polyethylene, doi: $10.2166 /$ wst.2016.414 polypropylene, polyvinylchloride, polystyrene, and polyethylene terephthalate (or polyester) (Zarfl \& Matthies 20Io; Ivar do Sul \& Costa 20I4). Consequently, the majority of released plastic pollutants in the environment are composed of these polymers (Ivar do Sul et al. 20I4).

Microplastics, which are plastic fragments in the micrometer size range $(<1 \mathrm{~mm})$ (Browne et al. 20II), are available to a wide range of aquatic organisms as they occupy the same size range as their natural food sources (Zhao et al. 20I4). Microplastics have the capacity to interact with a variety of contaminants in the surrounding environment (Holmes et al. 20I2; Bakir et al. 20I4; Wang et al. 20I5), which may also pose a risk for aquatic organisms. Further, additives that are included in the polymer structure during manufacturing may also lead to harmful consequences if they are leached to exposed organisms (Browne et al. 2013). Nevertheless, the degree to which various microplastics themselves and their associated contaminants may cause a risk to aquatic organisms still remains poorly understood. 
Generally the sources of microplastics in the aquatic environment have been classified as (i) aquatic-based sources and (ii) land-based sources and include both, primary or secondary microplastics (Law et al. 20Io; Hammer et al. 2012; Eriksen et al. 2013 b). Primary microplastics are manufactured as microplastics, while secondary microplastics are produced from the breakdown of larger plastic particles (Zhao et al. 20I4). Aquatic-based microplastics may originate from the degradation of larger plastic objects discarded through human activities, such as littering, fishing and shipping activities, and are considered as secondary microplastics (Hammer et al. 20I2). Land-based sources include run-off containing microplastics (solid wastes). After heavy rainfall microplastics can be flushed into the aquatic environment, especially from poorly managed or illegal landfills (Teuten et al. 2009; Hammer et al. 2012; Wagner et al. 20I4; Duis \& Coors 20I6), and these particles can also be classified as secondary microplastics given that they undergo breakdown before entering the aquatic environment (Eerkes-Medrano et al. 20I5). Wastewater treatment plant (WWTP) effluent is another land-based source of microplastics (Cole et al. 20II; Wagner et al. 20I4; EerkesMedrano et al. 20I5) and can include both primary and secondary microplastics. Depending on the wastewater treatment facilities, effluent may be released directly into the ocean or into the fresh water environment, such as rivers or lakes, which may then be transported to the marine environment (McCormick et al. 2014).

While land-based sources are assumed as one of the most important sources of microplastics (da Costa et al. 20I6), there is a lack of quantitative estimation on the relative contribution of different sources to the total concentration of microplastics in the aquatic environment (Koelmans et al. 2014; Duis \& Coors 2016).

Amongst the different sources of microplastics to the aquatic environment, wastewater effluent has recently received considerable attention as a potential point source of microplastics (Browne et al. 20II; Carr et al. 20I6). However, the contribution of microplastics released via wastewater effluent compared to other sources is largely unknown (Magnusson \& Norén 20I4; Eerkes-Medrano et al. 20I5).

The importance of WWTP effluent as a source of microplastics may increase in the future, given current population growth as well as rapid urbanization and industrialization, which can lead to increasing volumes of wastewater (UNEP 20IO; Browne et al. 20II). Subsequently, the contribution of wastewater-based microplastics into the receiving environment may continue to increase if its importance is not fully realised and no further actions are taken to prevent and reduce microplastics in wastewater.

The current review highlights the presence and potential importance of WWTP effluent as one of the sources of microplastics in the aquatic environment by reviewing the current state of knowledge. The review will also provide an in-depth analysis on the fate of microplastics in WWTPs, the potential mechanisms involved in the interaction of wastewater-based microplastics and trace organic contaminants (TrOCs), and the adverse effects of microplastics and their associated TrOCs from a risk-based perspective. The review will conclude by highlighting areas of future research.

\section{SOURCES OF WASTEWATER-BASED MICROPLASTICS INTO THE AQUATIC ENVIRONMENT}

Over the last few years, various types of microplastics with a suspected WWTP origin have been reported in aquatic ecosystems (Table 1). One of the common wastewater-based microplastics include microbeads, such as polyethylene and polypropylene, which contribute to over $90 \%$ of microbeads associated with cosmetic and personal care products (Zitko \& Hanlon I99I; Fendall \& Sewell 2009; Leslie 20I4; Wagner et al. 2014; Dris et al. 2015c; Gouin et al. 20I5). While a number of cosmetic companies have voluntarily started to remove plastic microbeads from their products and replace them with natural compounds (Gouin et al. 20I5), it was recently reported that 80 body and facial scrub products in the UK market still contain polyethylene microbeads that can be consumed by millions of consumers worldwide (Beat the Microbeads 20I5; Napper et al. 20I5). Moreover, a very recent study of eight municipal WWTPs effluent across Southern California revealed that the majority (over 90\%) of detected microplastics had a profile resemble the blue polyethylene microplastics extracted from toothpaste (Carr et al. 2016). Thus, microbeads in personal care products are currently an important potential source of microplastics in WWTP effluent.

Recently, the US Government established the 'Microbead-Free Waters Act of 2015', which prohibits the production or sale of rinse-off personal care products (e.g. toothpaste or facial scrubs) containing microbeads from 2017 (Congress.gov. 20I5).

Other plastic polymers also used in cosmetic products include polylactic acid, polyethylene terephthalate (Rochman et al. 20I5), polyethylene isoterephthalate, nylon-12, 
Table 1 | Some studies detecting microplastics in the aquatic environment pointing to a suspected wastewater origin

\begin{tabular}{|c|c|c|c|c|}
\hline Study & Study location & $\begin{array}{l}\text { Sampled } \\
\text { environment }\end{array}$ & $\begin{array}{l}\text { Average abundance of } \\
\text { sampled microplastics }\end{array}$ & $\begin{array}{l}\text { Mesh size of } \\
\text { sampling method }\end{array}$ \\
\hline $\begin{array}{l}\text { Zhao et al. } \\
\text { (20I4) }\end{array}$ & $\begin{array}{l}\text { Yangtze Estuary and the } \\
\text { coastal waters of the } \\
\text { East China Sea }\end{array}$ & $\begin{array}{l}\text { Surface } \\
\text { water }\end{array}$ & $\begin{array}{l}\text { 4,137 particles } / \mathrm{m}^{3} \text { in } \\
\text { Yangtze Estuary, and } \\
0.167 \text { particles } / \mathrm{m}^{3} \\
\text { coastal waters of East } \\
\text { China Sea }\end{array}$ & $\begin{array}{r}333 \mu \mathrm{m} \text { mesh } \\
\text { neuston net }\end{array}$ \\
\hline $\begin{array}{l}\text { Castañeda } \\
\text { et al. (20I4) }\end{array}$ & $\begin{array}{l}\text { St. Lawrence River, } \\
\text { Canada }\end{array}$ & Sediment & 13,832 particles $/ \mathrm{m}^{2}$ & $500 \mu \mathrm{m}$ sieve \\
\hline $\begin{array}{l}\text { Claessens } \\
\text { et al. (2OII) }\end{array}$ & Belgian coast & Sediment & $\begin{array}{l}37,000-149,000 \text { particles/ } \\
\mathrm{m}^{2}\end{array}$ & $\begin{array}{l}\text { Bulk sample of } \\
\text { sediment was } \\
\text { taken and } \\
\text { passed } \\
\text { through } \\
38 \mu \mathrm{m} \text { mesh }\end{array}$ \\
\hline
\end{tabular}

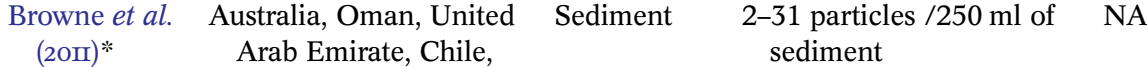
Philippines, Portugal, USA, South Africa, Mozambique, United kingdoms

$\begin{array}{ll}\begin{array}{c}\text { Dris et al. } \\ (\text { (20I5a })^{*}\end{array} & \text { River Seine, France } \\ & \\ \text { Eriksen et al. } & \text { Lakes Superior, Hu} \\ (\text { 20I3a }) & \text { and Erie, USA } \\ & \\ & \\ \text { Gallagher } & \text { Solent Estuarine } \\ \text { et al. (20I5) } & \text { Complex, UK }\end{array}$

Surface
Water

Surface water

Water column
30 and 0.35 particles $/ \mathrm{m}^{3}$ for plankton net and manta trawl, respectively

43,000 particles/ $/ \mathrm{km}^{2}$

Total of 2,759 particles of four different sampling site
80 and $330 \mu \mathrm{m}-$ mesh, plankton net and manta trawl

\section{$333 \mu \mathrm{m}$ mesh manta trawl}

$300 \mu \mathrm{m}$ plankton net trawl
Origin of sampled microplastics

Approximately 80\% were fibres, which were suspected to derive from sewage and/or from degradation of rope material and fishery activities.

99.9\% of polyethylene microbeads had the similar size, shape and chemical composition of microbeads in cosmetic products

Nylon and polypropylene fibres following polyethylene and polypropylene fragments were the dominant type of microplastics that were suggested to be associated with carpet and clothing and cosmetic products, respectively

The dominant types of collected microplastics were polyester and acrylic, followed by polypropylene, polyethylene, and polyamide fibres, with detected fibres similar to fibres found in wastewater effluent, most likely from washing synthetic clothes

The dominant type of sampled microplastics were fibres and urban water system discharges, including wastewater, was considered as one of the sources of the detected microplastics.

Many microplastics were multicoloured with a spherical shape and were suspected to be microbeads from cosmetic products associated with wastewater

The majority of detected microplastics were fibres (expected to be polyester) and rounded pellets (expected to be polyethylene and polypropylene), which were likely to be associated with wastewater effluent discharge. 
Table 1 | continued

\begin{tabular}{|c|c|c|c|c|c|}
\hline Study & Study location & $\begin{array}{l}\text { Sampled } \\
\text { environment }\end{array}$ & $\begin{array}{l}\text { Average abundance of } \\
\text { sampled microplastics }\end{array}$ & $\begin{array}{l}\text { Mesh size of } \\
\text { sampling method }\end{array}$ & Origin of sampled microplastics \\
\hline $\begin{array}{l}\text { Talvitie et al. } \\
\qquad(2 \mathrm{OI} 5)^{*}\end{array}$ & $\begin{array}{l}\text { Helsinki archipelago } \\
\text { coastal Gulf of } \\
\text { Finland. }\end{array}$ & $\begin{array}{l}\text { Water } \\
\text { column \& } \\
\text { sediment }\end{array}$ & $\begin{array}{l}0.01 \text { and } 0.65 \text { fibres/L, } 0.5 \\
\text { and } 9.4 \text { synthetic } \\
\text { particles/L }\end{array}$ & $\begin{array}{c}20-200 \mu \mathrm{m} \\
\text { using a } \\
\text { filtration } \\
\text { device }\end{array}$ & $\begin{array}{l}\text { The fibres and synthetic particles } \\
\text { with properties similar to } \\
\text { microplastics detected in } \\
\text { wastewater effluent were found } \\
\text { in the receiving water body of } \\
\text { a WWTP. }\end{array}$ \\
\hline $\begin{array}{l}\text { McCormick } \\
\text { et al. (20I4) }\end{array}$ & $\begin{array}{l}\text { North Shore Channel, } \\
\text { Illinois, USA }\end{array}$ & $\begin{array}{l}\text { Surface } \\
\text { water }\end{array}$ & $\begin{array}{l}17.93 \text { particles } / \mathrm{m}^{3} \\
\text { downstream of WWTP } \\
\text { effluent input } \\
1.94 \text { particles } / \mathrm{m}^{3} \\
\text { upstream, of WWTP } \\
\text { effluent input }\end{array}$ & $\begin{array}{l}333 \mu \mathrm{m} \text { mesh } \\
\text { neuston nets }\end{array}$ & $\begin{array}{l}1.21 \text { and } 10.57 \text { particles } / \mathrm{m}^{3} \text { were } \\
\text { fibres and } 0.45 \text { and } 0 \text { particle/ } \\
\mathrm{m}^{3} \text { were pellet, in downstream } \\
\text { and upstream samples, } \\
\text { respectively. Microplastics } \\
\text { were suspected to be } \\
\text { associated with synthetic } \\
\text { textiles and cleansing products } \\
\text { in wastewater. }\end{array}$ \\
\hline $\begin{array}{l}\text { Woodall } \\
\text { et al. (20I4) }\end{array}$ & $\begin{array}{l}\text { Mediterranean Sea, SW } \\
\text { Indian Ocean and NE } \\
\text { Atlantic Ocean }\end{array}$ & Sediment & $\begin{array}{l}14,000 \text { particles } / \mathrm{m}^{2} \text { of } \\
\text { Indian Ocean Sediment }\end{array}$ & $\begin{array}{l}\text { Collected } \\
\text { sediments } \\
\text { passed } \\
\text { through } \\
32 \mu \mathrm{m} \text { mesh } \\
\text { sieve }\end{array}$ & $\begin{array}{l}\text { The dominant type of detected } \\
\text { fibres was polyester }(53 \%) \\
\text { followed by polyamide }(34 \%) \\
\text { and acrylic }(12 \%) \text {. Textile was } \\
\text { suggested as one of the } \\
\text { potential sources. }\end{array}$ \\
\hline
\end{tabular}

Note: $70 \mathrm{~kg}$ sediment, $0.1 \mathrm{~m}^{2}$ of sampling site (Claessens et al. 2011).

Note: 'NA': Not available.

*Studies that confirmed wastewater as a source of detected microplastics using Fourier transform infrared spectroscopy.

nylon-6, poly(methyl methylacrylate), polytetrafluoroethylene, and polyurethane (Leslie 2014), and these polymers may enter into wastewater effluent following production and use of those products. Additionally, microplastics with physical properties that resemble microbeads, such as polyethylene, polystyrene and thermoset polyester polymer applied in air and sand blasting technologies, are also a potential source of microplastics in wastewater (Eriksen et al. 20I3a).

Microfibers, such as polyester, acrylic, and nylon associated with clothes, carpets and other textile products (Browne et al. 2007; Browne et al. 20п; Claessens et al. 20II), may unintentionally find their way into the aquatic environment via wastewater during washing and/or manufacturing of synthetic fibres and represent another type of wastewater-based microplastics (Teuten et al. 2007; Browne et al. 20II; Law \& Thompson 2014; Driedger et al. 2015; Rocha-Santos \& Duarte 20I5). More than 100 fibres per litre of laundry wastewater can be released into WWTPs from washing polyester clothes (Browne et al. 20II; Dris et al. 20I5c). Thus, textile and carpet industries as well as commercial laundries are likely to release significant amounts of microplastic fibres to WWTPs and, depending on the level of treatment, this wastewater effluent may represent a relatively large source of microplastic fibres. However, this has yet to be estimated. McCormick et al. (2014) reported high concentrations of microplastics, mostly fiber associated with synthetic fabrics, in the North Shore Channel of the Chicago River, which receives secondary effluent from a domestic treatment plant that currently operates with the secondary clarifiers (Storm Water Solution 20I3).

Microplastics with a similar shape and composition as microbeads used in cosmetic products have been detected in surface waters from three of the Great Lakes in North America, with their source suspected to be wastewater effluent discharge (Eriksen et al. 2013a). This finding was supported by the detection of microbeads in wastewater effluent discharged into the Great Lakes (Schneiderman 20I5). Further, Claessens et al. (20II) found high concentrations of microplastics with the dominant shape of fibres and granules in marine sediment along the Belgian coast. Although, this study was not able to determine the source of the detected microplastics, it was speculated that the granules, which included polyethylene and polypropylene, were likely to have originated from cosmetic products, air blasting media and the plastics industry. Additionally, a 
proportion of fibres, such as nylon, were suspected to be derived from fibrous material including clothes and carpets (Claessens et al. 20II), and thus are likely to be associated with domestic and/or industrial wastewater discharge.

Deep-sea sediments sampled at different locations worldwide, including the Mediterranean Sea, South West Indian Ocean and North East Atlantic Ocean, showed that polyester and acrylic polymers contributed to the majority $(86 \%)$ of analyzed microplastics and were suspected to derive from sources such as packaging material, electronics and textiles (Woodall et al. 20I4). wastewater was suggested as one of the potential sources of microplastics in all above studies, the actual contribution of wastewater to the detected microplastics has yet to be established. In contrast, Klein et al. (20I5) detected microplastics in sediment along the shore of the Rhine and Main Rivers in Germany and found lower concentrations of microplastics near WWTPs compared to other monitored areas, with no relationship between the number of microplastics detected and the proximity to WWTPs found. Moreover, the detected microplastics primarily included polyethylene, polypropylene and polystyrene, which suggests they originate from discarded plastic products, as these polymers comprise $55.7 \%$ of European plastic demand (Klein et al. 20I5).

A number of factors may affect the contribution of wastewater as a source of microplastics and also the dominant type of wastewater-based microplastics in a specific area including (i) population density, (ii) the number and type of industries involved in producing plastics, (iii) the level of wastewater treatment, (iv) the public awareness with respect to microplastics and their subsequent effects and (v) waste management processes (Free et al. 2014; Jambeck et al. 20I5). The correlation between some of the above-mentioned factors and input into aquatic environment has been reported for other pollutants (Abril et al. 2002). Thus, it is likely that highly populated and industrialized communities with low levels of wastewater treatment, as well as inefficient waste disposal management, may be major contributors to the release of wastewater-based microplastics to the environment. It is reported that $90 \%$ of all wastewater in developing countries is discharging untreated to the aquatic environment such as lakes, rivers and the oceans (UNEP 20IO).

\section{FATE OF WASTEWATER-BASED MICROPLASTICS IN WWTP}

While the presence of wastewater-based microplastics in the aquatic environment has recently attracted the attention of scientists (Fendall \& Sewell 2009; Cole et al. 20II; Eriksen et al. 2013a; McCormick et al. 2014), less attention has been drawn to the fate of microplastics during wastewater treatment (Duis \& Coors 2016).

Before returning to the aquatic system, wastewater may be treated in WWTPs. Depending on the type and scale of the facility, a WWTP can have primary, secondary and tertiary treatment trains to purify the influent using physical, chemical and biological treatment processes. During physical and chemical processes many suspended and floating solids including plastic particles are removed through screening, sedimentation, flotation, coagulation-flocculation and filtration within treatment ponds or settling tanks (Stephenson 2009). These processes generally capture a large amount of solid particles, which may include plastic debris depending on the size and density of particles as well as the size of the screen bars and filters (Stephenson 2009). The degree to which these process can specifically remove microplastics has recently been investigated by Talvitie et al. (20I5), who found that the number of microfibres in wastewater influent reduced from 180 fibres per litre to 14.2 and 13.8 fibres per litre after primary and secondary sedimentation processes, respectively.

To investigate the fate of microplastics during treatment processes and the role of wastewater as a source of microplastics, it is necessary to estimate the mass of microplastics entering WWTPs and the amount released with wastewater effluent. Recently, there have been a number of pilot studies assessing the load of microplastic in WWTPs in Europe, Russia and the US (HELCOM 20I4; Magnusson \& Norén 20I4; Schneiderman 2015), with the results summarised in Table 2. One such study demonstrated that mechanical, chemical and biological treatment can remove about $99 \%$ of microplastics, from 15,000 particles/L in the influent to 8 particles/L in the effluent (Magnusson \& Norén 2014). Likewise, in a Russian WWTP the number of microplastics (textile fibres) reduced from 467 particles/L in the influent to 16 particles/ $L$ in the effluent ( $96 \%$ reduction in microplastics after the secondary treatment) (HELCOM 20I4). While this is a promising finding, given the volume of treated wastewater of 2.18 million $\mathrm{m}^{3} / \mathrm{d}$ from the above Russian WWTP (Vodokanal 20I5), over $34 \times 0^{9}$ particle/L are still discharged to the receiving environment every day. A recent study on a WWTP in Finland also reported an average concentration of 4.9 and 8.6 microplastic fibres and particles, respectively, per litre in tertiary treated effluent ( $\sim 98 \%$ removal after tertiary treatment) (Talvitie et al. 20I5). Therefore, a daily discharge of $1,323 \times$ $10^{6}$ fibres and $2,322 \times 10^{6}$ particles to the receiving 
Table 2 | Some reviews of used techniques to detect microplastics in wastewater and reported results

\begin{tabular}{|c|c|c|c|c|c|c|c|c|c|}
\hline Study & $\begin{array}{l}\text { Study } \\
\text { country }\end{array}$ & $\begin{array}{l}\text { Sampling } \\
\text { method }\end{array}$ & $\begin{array}{l}\text { Size range of } \\
\text { sampled } \\
\text { particles }(\mu \mathrm{m})\end{array}$ & $\begin{array}{l}\text { Identification } \\
\text { method }\end{array}$ & $\begin{array}{l}\text { Dominant shape \& } \\
\text { type of detected } \\
\text { microplastics }\end{array}$ & $\begin{array}{l}\text { Number of } \\
\text { microplastics } \\
\text { influent }\end{array}$ & $\begin{array}{l}\text { Number of } \\
\text { microplastics in final } \\
\text { effluent }\end{array}$ & Treatment type & Removal rate \\
\hline $\begin{array}{l}\text { Talvitie et al. } \\
\text { (20I5) }\end{array}$ & Finland & $\begin{array}{c}\text { Filtration } \\
\text { device }\end{array}$ & $20-200$ & $\begin{array}{l}\text { Visual } \\
\text { observation \& } \\
\text { FT-IR } \\
\text { spectroscopy }\end{array}$ & $\begin{array}{l}\text { Synthetic particle } \\
\text { and textile } \\
\text { fibres }\end{array}$ & $\begin{array}{l}430 \text { synthetic } \\
\text { particle/L, } \\
180 \text { textile } \\
\text { fibres/L }\end{array}$ & $\begin{array}{l}8.6 \text { synthetic } \\
\text { particle/L, } \\
4.9 \text { textile fibres/ } \\
\text { L }\end{array}$ & Tertiary & $\begin{array}{l}98 \% \\
\text { synthetic } \\
\text { particle, } \\
97 \% \text { for } \\
\text { fibres }\end{array}$ \\
\hline $\begin{array}{l}\text { Dris et al. } \\
\quad(2015 \mathrm{~b})\end{array}$ & France & $\begin{array}{r}\text { Automatic } \\
\text { sampler }\end{array}$ & ND & $\begin{array}{l}\text { Visual } \\
\text { observation }\end{array}$ & Fibres & $\begin{array}{l}\text { 260-320 particle } \\
\text { /L }\end{array}$ & 14-50 particle/L & $\begin{array}{l}\text { Primary \& } \\
\text { biological } \\
\text { treatment }\end{array}$ & $84-94 \%$ \\
\hline $\begin{array}{l}\text { Murphy et al. } \\
\text { (2016) }\end{array}$ & Scotland & $\begin{array}{l}\text { Steel bucket } \\
\text { and steel } \\
\text { sieve }\end{array}$ & $>65$ & $\begin{array}{l}\text { Visual } \\
\quad \text { observation \& } \\
\text { FT-IR } \\
\text { spectroscopy }\end{array}$ & $\begin{array}{l}\text { Fibres (polyester, } \\
\text { polyamide, } \\
\text { acrylic) }\end{array}$ & 15.7 particle/L & 0.3 particle/L & Secondary & $98.41 \%$ \\
\hline $\begin{array}{l}\text { Carr et al. } \\
\quad(2016)\end{array}$ & U.S & Sieving & $20-400$ & $\begin{array}{l}\text { Visual } \\
\text { observation \& } \\
\text { FT-IR } \\
\text { spectroscopy }\end{array}$ & $\begin{array}{l}\text { Irregularly } \\
\text { shaped } \\
\text { polyethylene }\end{array}$ & 1 particle/L & $\sim 0.0007$ particle/L & Tertiary & $99.9 \%$ \\
\hline $\begin{array}{l}\text { Magnusson } \\
\text { and Norén } \\
(2014)\end{array}$ & Sweden & Filtration & $>300$ & $\begin{array}{l}\text { Visual } \\
\text { observation \& } \\
\text { FT-IR } \\
\text { spectroscopy }\end{array}$ & $\begin{array}{l}\text { Fibres and } \\
\text { fragment }\end{array}$ & 15 particle/L & 8.3 particle/L & $\begin{array}{l}\text { Mechanical, } \\
\text { chemical \& } \\
\text { biological }\end{array}$ & $99.9 \%$ \\
\hline $\begin{array}{l}\text { HELCOM } \\
(\text { (20I4) }\end{array}$ & Russia & $\begin{array}{l}\text { A filtration } \\
\text { device }\end{array}$ & $20-300$ & $\begin{array}{l}\text { Visual } \\
\text { observation }\end{array}$ & $\begin{array}{l}\text { Fibres \& } \\
\text { synthetic } \\
\text { particle }\end{array}$ & $\begin{array}{l}467 \text { fibres } / \mathrm{L}, \\
160 \text { synthetic } \\
\text { particle/L }\end{array}$ & $\begin{array}{c}16 \text { fibres/L, } \\
7 \text { synthetic } \\
\text { particle/L }\end{array}$ & $\begin{array}{l}\text { Mechanical } \\
\text { treatment and } \\
\text { purification }\end{array}$ & $96 \%$ \\
\hline $\begin{array}{l}\text { Browne et al. } \\
\quad(20 I I)\end{array}$ & Australia & $\begin{array}{l}\text { Glass bottle } \\
\text { (750 ml }) \\
\text { filtration }\end{array}$ & ND & $\begin{array}{l}\text { Visual } \\
\quad \text { observation \& } \\
\text { FT-IR } \\
\text { spectroscopy }\end{array}$ & Fibres & ND & 1 particle/L & Tertiary & ND \\
\hline
\end{tabular}

Note: 'ND': Not detected; 'FT-IR': Fourier transform infrared spectroscopy. 
environment can be expected from that one WWTP, given a flow rate of around 270 million litres of wastewater per day (Talvitie et al. 2015). Carr et al. (2016), reported the removal efficiency of $99.9 \%$ of microplastics in tertiary WWTPs in the U.S, with total daily discharge of $0.93 \times 10^{6}$ microplastics. It should be noted that the lack of a uniform and standardized method for sampling, sample processing and analysis of microplastics may lead to incomparable results. The methods used by some studies that detect microplastics in WWTPs are shown in Table 2.

Thus, while 96 to $99.9 \%$ is a significant reduction, the small percentage remaining in the effluent is likely to nevertheless represent an important source of microplastics to the aquatic environment given the large volume of effluent produced annually.

Currently, WWTPs are not specifically designed to remove microplastics from the wastewater effluent (Schneiderman 20I5). However, the results of recent studies showed that the majority of microplastics are captured through skimming of floating solids during the primary treatment stage (Carr et al. 20I6; Murphy et al. 20I6). In this process microplastics removal is more dependent on density rather than size, as lower density microplastics may float and be removed by surface skimming (Carr et al. 20I6). Moreover, there is evidence that tertiary treatment showed greater removal of microplastics compare to secondary and primary (Talvitie et al. 20I5). Analyzing the final effluent of a German WWTP revealed that advanced filtration could only remove 93\% of microplastics in the size range of $<500 \mu \mathrm{m}$ ([Mintenig et al. 2014] as cited in Duis \& Coors 2016). More research is needed to assess the capacity of WWTPs to capture microplastics.

The physiochemical properties of microplastics can be altered during treatment processes. A recent study provides evidence regarding the presence of a layer of biofilm on the observed wastewater-based microplastic. These biofilms may influence the surface properties and relative density of microplastics (Carr et al. 20I6), and consequently the fate of wastewater-based microplastics in the aquatic environment. Further, Lobelle \& Cunliffe (2OII) showed that biofilm can significantly modify the physiochemical properties of plastic debris, by making them less hydrophobic and more buoyant. Further research is required to study physical and chemical modifications of microplastics during wastewater treatment processes.

When considering the fate of microplastics in WWTPs another important issue is what happens to the retained microplastics. It has been reported that a large proportion of the captured microplastics will be retained in the sludge phase (Magnusson \& Norén 20I4), with a number of studies finding high concentrations of microplastics in WWTP sludge samples (Brandsma et al. 2014; Magnusson \& Norén 20I4; Carr et al. 2016). Carr et al. (2016) reported 5 microplastic particles in $5 \mathrm{~g}$ of biosolid samples of a WWTP that based on the daily production of biosolid, $1.9 \times 10^{9}$ particles is estimated to remove daily with the biosolid. Thus, the use of treated sewage sludge as biosolid may be an important source of microplastics to the environment given their wide application in agriculture and forestry for soil amendment (Rillig 20I2; Dris et al. 20I5c; EerkesMedrano et al. 20I5; Rocha-Santos \& Duarte 20I5). It is also suggested that a proportion of microplastics in soil may eventually enter the aquatic environment via run off after heavy rain, irrigation or by transportation by the wind (Hammer et al. 2012; Rochman et al. 2015).

\section{INTERACTION OF MICROPLASTICS WITH TROCS AND METAL IONS}

Given that wastewater contains a large number of organic and inorganic pollutants, it is likely that microplastics can interact with the variety of contaminants present in wastewater. This can potentially make microplastics carriers of wastewater-based contaminants, including industrial chemicals, pharmaceuticals, hormones, pesticides and metal ions, and thus modify their environmental fate. Using the textile industry as an example, substantial amounts of chemicals are used in bleaching, dyeing and finishing processes, thus auxiliary chemicals and heavy metals such as $\mathrm{Cr}, \mathrm{As}, \mathrm{Cu}$ and $\mathrm{Zn}$ can be released into the wastewater (Carmen \& Daniela 20I2; Ghaly et al. 20I3) and can potentially interact with the microfibres associated with textiles.

The interaction of microplastics and metal ions such as $\mathrm{Al}$, Fe, Mn, Cu, Zn, Pb, Ag, Cd, Co, Sr, Mo, Sb, Sn, and Ni and the capacity of plastics to act as a 'transport vector' of toxic metals has been extensively reported in the literature (Ashton et al. 20I0; Holmes et al. 20I2; Nakashima et al. 20I2; Rochman et al. 20I4). Metallic sorption can occur in both aged/weathered and virgin microplastics. It was assumed that the sorption mechanism in weathered microplastics would occur through the interaction of bivalent cations and oxyanions with the charged regions of modified plastic surfaces (Holmes et al. 20I2; Holmes et al. 20I4). However, it was demonstrated that the interaction of virgin microplastics and trace metals $(\mathrm{Cd}, \mathrm{Co}, \mathrm{Ni}, \mathrm{Pb})$ occurs through the rapid adsorption of existing organic matter in water to the surface of the microplastics, leading 
to the acquisition of a negative charge from the organic matter function groups, due to the fact that virgin plastics do not exhibit inherent charge or acid-base behaviour (Holmes et al. 2014). Therefore, the potential interaction of microplastics with metal ions in wastewater, as well as the common treatment chemicals, such as aluminium and iron used for flocculation-coagulation processes (Ukiwe et al. 20I4), may be an issue that needs further investigations.

In both the laboratory and the field, microplastics have been shown to sorb a wide range of TrOCs at many orders of magnitude higher than the surrounding water, with the reported concentrations ranging from 1 to $10,000 \mathrm{ng} / \mathrm{g}$ (Rios et al. 2010; Koelmans et al. 2013). Further, microplastics are able to accumulate more contaminants in highly polluted environments, such as industrial areas (Frias et al. 20I0; Hirai et al. 20п; Karapanagioti et al. 20п; Antunes et al. 20I3; Mizukawa et al. 2013). Thus, it is expected that microplastics in wastewater will behave similarly and will be able to accumulate high concentrations of TrOCs and metals. The sorption of some organic pollutants including dichlorodiphenyltrichloroethane (DDT) and phenanthrene to polyethylene microbeads extracted from shower gel has recently been showed to be comparable with the sorption capacity of polyethylene originated from other sources (Napper et al. 2015). Moreover, there is evidence of the interaction of microplastics and wastewater derived TrOCs, such as perfluorooctanesulfonate (PFOS) and perfluorooctanesulfonamide (PFOSA), with perfluorochemicals found frequently in municipal and industrial wastewater and sewage sludge (Ma \& Shih 20I0; Wang et al. 20I5). To date, research on the interaction of microplastics and TrOCs has mainly focused on the marine environment, and more recently fresh water and estuarine environments, but the sorption behaviour and chemical fate of microplastics in wastewater still remains unexplored.

\section{Sorption capacity of microplastic for Trocs}

The sorption of TrOCs to microplastics polymers is likely to occur through (i) absorption and (ii) adsorption mechanisms, which are strictly dependent on the physico-chemical characteristics of both TrOCs and microplastic (Mato et al. 200I; Matsuzawa 20I0; Rochman et al. 20I3a). Thus, different microplastics are expected to show different sorption affinities for different types of TrOCs.

Adsorption is assumed to be the general sorption mechanism that would occur not only through the interaction of hydrophobic surfaces of the polymer and TrOCs (Matsuzawa 20I0) (non-polar surface interaction/hydrophobic interaction), but also by specific interactions, such as electrostatic interactions and hydrogen bonding (Pan \& Xing 2008). The polymer adsorption capacity to uptake TrOCs is likely to be positively correlated with the polymer surface area, which provides more adsorption sites at the surface of the polymer (Teuten et al. 2007; Fotopoulou \& Karapanagioti 20I2; Rochman et al. 2013a; Rochman 2015). Thus, the smaller the microplastic size, the more surface area and consequently the greater the sorption capacity (Rochman 20I5). The surface interaction is likely to reach a threshold once the adsorption sites are saturated and the time required to reach the saturation may also vary depending on the polymers and TrOCs (Rochman et al. 2013a).

Absorption, on the other hand, refers to the diffusion of contaminants into the matrix of sorbent, which is strongly associated with the polymer molecular structure (Rochman et al. 20rza). Polymers have been classified as rubbery and glassy based on their molecular structure (Crawford ig98). The structure of glassy polymers is more condensed, with little void spaces, whilst rubbery polymers exhibit greater flexibility, with large amounts of free volumes between molecules (Teuten et al. 2009; Bakir et al. 20I2). It has been shown that rubbery polymers, such as polyethylene and polypropylene, have a greater sorption capacity for TrOCs, such as phenanthrene, DDT, polychlorinated biphenyl and polycyclic aromatic hydrocarbons compared to glassy polymers, such as polyvinyl chloride (PVC) (Bakir et al. 2012; Rochman et al. 20Iza). Consequently, it is obvious that the sorption capacity of microplastics for TrOCs varies appreciably among different types of polymer depending on their surface area, crystallinity and diffusivity (Rochman et al. 20I3a; Rochman 2015).

While specific types of polymer may show a high tendency to sorb a specific class of TrOCs, this may not extend to all classes of TrOCs (Rochman et al. 20Iza; Rochman 20I5). The chemical properties of TrOCs such as hydrophobicity (octanol-water partition coefficient, $\log \mathrm{K}_{\mathrm{ow}}$ ) and molecular weight (Smedes et al. 2009) can also affect the sorption rate and the equilibrium time (Rochman et al. 20I3a).

Other factors that are likely to affect the partition behaviour and sorption rate of a TrOC to microplastics are (i) the concentration of organic matter and (ii) the presence of other contaminants in the system. The relative importance of organic matter compared to microplastics for sorption of hydrophobic TrOCs has been recently suggested using a multimedia model (Gouin et al. 20II). Based on an environmental realistic volume ratio of polyethylene to organic matter $\left(1: 1.26 \times 10^{7}\right)$ for the marine coastal system, it has been predicted that the majority of TrOCs, even those with 
a high polyethylene-water partition coefficient $\left(\log \mathrm{K}_{\mathrm{PE}}-\mathrm{w}>7\right)$, will tend to partition more (>99\%) to organic matter than polyethylene (Gouin et al. 20II). Thus, the organic mattermicroplastic volume ratio may also affect the sorption rate of TrOCs to microplastics. This is particularly relevant for wastewater-based microplastics, as wastewater can contain high concentrations of organic matter, microplastics and TrOCs.

The competition behaviours between various TrOCs to sorb to microplastics can also influence the sorption rate of a TrOC to microplastics (Bakir et al. 20I2). Given that wastewater will contain a complex mixture of TrOCs, it is likely that the sorption capacity of TrOCs by microplastics in wastewater would be lower than expected based on single compound experimental studies (Bakir et al. 2012). More research is required to investigate sorption behaviour in real but more complex matrices, such as WWTP effluent.

\section{A RISK-BASED PERSPECTIVE OF BIOLOGICAL EFFECTS OF MICROPLASTICS ON AQUATIC ORGANISMS}

To evaluate the risk that microplastics may pose to aquatic organisms, it is important to understand to what extent microplastics and their associated contaminants contribute to adverse effects and subsequent health outcomes in aquatic organisms. Toxicity may be related to acute or chronic effects through short or long-term exposure to microplastics and/or associated contaminants (Hammer 2008).

\section{Biological effects of microplastics themselves}

The adverse health effects from exposure to microplastics can result from physical and/or chemical effects (Wright et al. 20r3b). According to a Marine Strategy Framework Directive Report, the possible direct detrimental effects of ingested microplastics include interference with enzyme production, nutrient dilution, reduced growth rate, decreased steroid hormone levels, delayed ovulation, reproductive failure and death (Galgani et al. 2010). Microplastics can also cause physical damage through accumulation in the digestive tract following ingestion (Wright et al. 2013b), although the amount of microplastics necessary to produce sub-lethal or lethal effects vary as the process is influenced by the type and sensitivity of the organism (Wright et al. 20I3a; Wright et al. 2013b), exposure duration (Eisler 2000), the daily uptake dose of microplastics through normal food ingestion, the egestion of microplastics through excrement and the retention time of microplastics in the organism's body, as well as the type, size and shape of ingested microplastics (Huang et al. 2010; Wright et al. 20I3b). To date, there is limited work on assessing the risks after exposure to a range of microplastic concentrations (Syberg et al. 20I5). Lee et al. (2013) reported reduced survival of copepods (Tigriopus japonicas) exposed to 0.05 and $0.5 \mu \mathrm{m}$ microplastic beads at concentrations of 1.25 and $25 \mathrm{mg} / \mathrm{L}$, respectively, and no effect of $6 \mu \mathrm{m}$ beads at concentrations as high as $25 \mathrm{mg} / \mathrm{L}$.

The negative effects of microplastics on exposed organisms have been reported even after short-term exposure duration. For instance, aggregated polyethylene microplastics were observed in digestive gland lysosomes in blue mussels (Mytilus edulis), which caused a considerable decrease in lysosomal membrane stability at the cellular level by increasing granulocytoma formation during $96 \mathrm{~h}$ exposure as a cellular self-protection response to contaminants (von Moos et al. 2012). The physical impact of unplasticized polyvinyl chloride (UPVC) microplastics within the size range of $20-100 \mu \mathrm{m}$ was also investigated on lugworms, where $30 \%$ and $50 \%$ depletion of lipid reserves was observed after exposure to $1 \%$ and 5\% PVC, respectively, and was directly associated with a reduction in feeding activity due to the long retention time of microplastics in the organism's gut (Wright et al. 20I3a). Similarly, a recent study with copepods exposed to $20 \mu \mathrm{m}$ polystyrene microbeads over $24 \mathrm{~h}$ showed reduced energy supplies and growth rate due to interference with feeding capacity at concentration of 75 particles $\mathrm{mL}^{-1}$, which were $10 \%$ of their available food (Cole et al. 20I5).

It should be noted that some studies have conversely shown that microplastics can have negligible effects on some organisms. Hamer et al. (2014), recently demonstrated limited physical effects on isopods (Idotea emarginata) after 6 months of continuous exposure to three different microplastic types (polystyrene microbeads, polystyrene fragments and polyacrylic fibers), under low and high concentrations, with $100 \%$ of the ingested microplastics detected in the feces and no accumulation in the organism's gut. Consequently, it is possible that some aquatic organisms may exhibit no negative effects to any concentrations of microplastics. Therefore, improved understanding of the adverse effect of microplastics requires a comprehensive risk assessment procedure that considers all factors mentioned above. Some studies on the effects of microplastics on various organisms, and the factors influencing biological effects, are summarized in Table 3. 
Table 3 | Some reviews of the biological effects of microplastics on various organisms

\begin{tabular}{|c|c|c|c|c|c|c|}
\hline Study & Exposed Organism & Polymer type \& size & Concentration & Retention time & Exposure duration & Biological effects \\
\hline $\begin{array}{l}\text { Browne et al. } \\
\quad(2008)\end{array}$ & Mussel (M. edulis) & $\begin{array}{l}\text { Polystyrene } \\
\qquad(3-9.6 \mu \mathrm{m})\end{array}$ & $0.51 \mathrm{~g} / \mathrm{L}$ & Over 48 days & 3 hours & No toxicological effects were observed \\
\hline $\begin{array}{l}\text { Carlos de Sa et al. } \\
\quad(2015)\end{array}$ & $\begin{array}{l}\text { Common goby } \\
\text { (P. microps) }\end{array}$ & $\begin{array}{l}\text { Polyethylene } \\
\quad(420-500 \mu \mathrm{m})\end{array}$ & $\begin{array}{l}30 \text { particles alone } \\
\& 15 \text { particles in } \\
\text { combination with } \\
15 \text { preys }\end{array}$ & NA & $3 \mathrm{~min}$ & $\begin{array}{l}\text { Reduction of predatory performance } \\
\text { and efficiency }\end{array}$ \\
\hline Cole et al. (2015) & $\begin{array}{l}\text { Copepod ( } C . \\
\text { helgolandicus) }\end{array}$ & Polystyrene $(20 \mu \mathrm{m})$ & 75,000 particles/L & NA & $\begin{array}{l}24 \text { hours and } 9 \\
\text { days }\end{array}$ & $\begin{array}{l}\text { Prolonged exposure to microplastics led } \\
\text { to: Reduction of carbon biomass that } \\
\text { may cause energetic deficiencies and } \\
\text { lower growth; producing smaller } \\
\text { eggs; and reduced hatching success }\end{array}$ \\
\hline Hamer et al. (20I4) & $\begin{array}{l}\text { Isopods (I. } \\
\text { emarginata) }\end{array}$ & $\begin{array}{l}\text { Polystyrene } \\
(1-100 \mu \mathrm{m}) \\
\text { microbeads and } \\
\text { fragments, and } \\
\text { polyacrylic fibres } \\
(20-2,500 \mu \mathrm{m})\end{array}$ & $\begin{array}{l}\text { - } 12 \text { or } \\
120 \text { microbeads/ } \\
\text { mg of food } \\
\text { - } 20 \text { or } \\
350 \text { fragments/ } \\
\text { mg of food } \\
\text { - } 0.3 \mu \mathrm{g} \text { fibers } / \mathrm{mg} \\
\text { food }\end{array}$ & $\begin{array}{l}\text { No retention } \\
\text { was observed }\end{array}$ & 6 to 7 weeks & $\begin{array}{l}\text { No adverse effects on survival or } \\
\text { growth rate were observed }\end{array}$ \\
\hline Peda et al. (2016) & $\begin{array}{l}\text { European sea bass } \\
\quad(\text { D. labrax })\end{array}$ & $\begin{array}{l}\text { PVC pellets } \\
\qquad(>300 \mu \mathrm{m})\end{array}$ & $\begin{array}{l}0.1 \%(\mathrm{~W} / \mathrm{W}) \text { of } \\
\text { their diet }\end{array}$ & NA & 30,60 , and 90 days & $\begin{array}{l}\text { - After } 30 \text { and } 60 \text { days of exposure: } \\
\text { the majority of studied organisms } \\
\text { showed moderate structural changes } \\
\text { such as, shortening and swelling of } \\
\text { villi, circulatory changes and } \\
\text { worsening of inflammatory changes } \\
\text { - After } 90 \text { days: half of the individuals } \\
\text { showed serious changes such as } \\
\text { reduction of perivisceral fat and } \\
\text { reduction of intestinal function } \\
\text { - No mortality were observed after } 90 \\
\text { days exposure }\end{array}$ \\
\hline
\end{tabular}




\begin{tabular}{|c|c|c|c|c|c|c|}
\hline Study & Exposed Organism & Polymer type \& size & Concentration & Retention time & Exposure duration & Biological effects \\
\hline Lee $e t$ al. (20I3) & $\begin{array}{l}\text { Copepod } \\
\quad \text { (T. japonicas) }\end{array}$ & $\begin{array}{l}\text { Polystyrene (three } \\
\text { sizes: } 0.05,0.5 \\
\text { and } 6 \mu \mathrm{m})\end{array}$ & $\begin{array}{l}\text { Acute toxicity test: } \\
0,6,13,31,63, \\
187,250 \text { and } \\
313 \mathrm{mg} / \mathrm{L} \\
\text { Chronic toxicity } \\
\text { test: } 0.125,1.25, \\
12.5 \text { and } 25 \mathrm{mg} / \mathrm{L}\end{array}$ & NA & $\begin{array}{l}96 \text { hours (Acute } \\
\text { effects) } \\
14 \text { days (chronic } \\
\text { effects) }\end{array}$ & $\begin{array}{l}\text { Acute effects: } \\
\text { - No mortality was observed with any } \\
\text { of three different sizes at the highest } \\
\text { concentration (acute NOAEC > } \\
313 \mathrm{mg} / \mathrm{L} \text { ) } \\
\text { Chronic effects: } \\
\text { - Mortality observed at } \\
\text { concentrations }>1.25 \mathrm{mg} / \mathrm{L} \text { for the } \\
0.05 \mu \mathrm{m} \text { particles (LOAEC }= \\
1.25 \mathrm{mg} / \mathrm{L} \text { ), with no effects on } \\
\text { fecundity } \\
\text { - Decrease fecundity in } 0.5 \mu \mathrm{m} \\
\text { particles at the lowest } \\
\text { concentrations (LOAEC }=0.125 \mathrm{mg} / \\
\mathrm{L} \text { ), and in survival at the highest } \\
\text { concentration tested } \\
\text { - Decrease in fecundity at the lowest } \\
\text { concentration tested (LOAEC }= \\
0.125 \mathrm{mg} / \mathrm{L} \text { ) and no effect on } \\
\text { survival with the } 6 \mu \mathrm{m} \text { beads }\end{array}$ \\
\hline $\begin{array}{l}\text { Davarpanah \& } \\
\text { Guilhermino (20I5) }\end{array}$ & $\begin{array}{r}\text { Microalgae } \\
\text { (T. chuii) }\end{array}$ & $\begin{array}{l}\text { Polyethylene micr- } \\
\text { spheres }(1-5 \mu \mathrm{m})\end{array}$ & 0.046 to $1.472 \mathrm{mg} / \mathrm{l}$ & NA & 96 hours & $\begin{array}{l}\text { No significant effects of } \\
\text { microplastics on the growth rate of } \\
\text { T. chuii were found up to a } \\
\text { concentration of } 1.472 \mathrm{mg} / \mathrm{l} \text {. }\end{array}$ \\
\hline $\begin{array}{l}\text { von Moos et al. } \\
\text { (20I2) }\end{array}$ & Mussel (M. edulis) & $\begin{array}{l}\text { Polyethylene } \\
\qquad(0-80 \mu \mathrm{m})\end{array}$ & $2.5 \mathrm{~g} / \mathrm{L}$ of sea water & NA & Up to 96 hours & $\begin{array}{l}\text { Strong inflammatory response, } \\
\text { disruption of lysosomal membrane } \\
\text { stability }\end{array}$ \\
\hline Wright et al. (20I3a) & $\begin{array}{l}\text { Lugworm ( } A . \\
\text { marina) }\end{array}$ & $\begin{array}{l}\text { UPVC (mean } \\
230 \mu \mathrm{m})\end{array}$ & $\begin{array}{l}0.5-5 \% \text { by weight } \\
\text { (mixed with } \\
\text { sediment) }\end{array}$ & $\begin{array}{l}\text { Prolonged } \\
\text { residence } \\
\text { time }\end{array}$ & 28 days & $\begin{array}{l}\text { Reduced feeding activity, reduced lipid } \\
\text { and available energy reserve, } \\
\text { inflammation }\end{array}$ \\
\hline
\end{tabular}


With an estimated $40.5-215 \mathrm{mg}$ of polyethylene (PE) $\mathrm{microbead} / \mathrm{person} / \mathrm{d}$ in the UK (Napper et al. 20I5), and assuming an average wastewater production of $150 \mathrm{~L} /$ person/d, the expected concentration of PE in UK wastewater is $0.27-1.4 \mathrm{mg} / \mathrm{L}$. This is in range of the lowest observable adverse effect concentration (LOAEC) reported in Lee et al. (20I3), indicating a potential risk to the aquatic environment from wastewater-based microplastics.

Another potential risk of microplastics for aquatic organisms may be from binding of microorganisms, such as pathogens and bacteria, to the microplastic surface, since wastewater-based microplastics have been shown to be covered with a layer of biofilm (Carr et al. 2016). Thus, more research is required to understand the possible interactions of microplastics with existing microorganisms in wastewater and during wastewater treatment (such as biological processes), as these microorganism communities may be transported to the receiving environment.

\section{Biological effects from contaminants associated with microplastics}

Considering the evidence of TrOC sorption to microplastics, it is conceivable that the toxicity of microplastics to organisms may be enhanced by the toxic effects of sorbed TrOCs. Indeed, studies have suggested that sorbed TrOCs can migrate from microplastics to exposed aquatic organisms (Browne et al. 20I3; Rochman et al. 20I3b; Chua et al. 2014).

A recent study by Luis et al. (20I5) demonstrated that the presence of polyethylene microplastics caused a significant increase in the toxicity of $\mathrm{Cr}$ (VI) in marine fish (Pomatoschistus microps) compared to chromium alone. Likewise, Avio et al. (2015) reported significant transfer of pyrene to marine mussels (Mytilus galloprovincialis) through ingestion of contaminated polystyrene and polyethylene microplastics.

Some studies have suggested that the transfer of sorbed TrOCs from contaminated microplastics to the organism is likely to be a less significant source compared to the other exposure pathways (Gouin et al. 20II; Koelmans et al. 20I3). Using a biodynamic model to simulate the uptake of TrOCs on plastics in a sediment-water system, Koelmans et al. (2013) found that the role of microplastics for TrOC bioaccumulation in marine lugworm was insignificant compared to other TrOC exposure pathways, such as dermal uptake and uptake from sediment. Moreover, a recent study has also demonstrated much lower uptake of PBDE, and subsequently lower health risks, in amphipods tissue after $72 \mathrm{~h}$ exposure to PBDE sorbed to polyethylene microplastics compared to those exposed to PBDE alone (Chua et al. 2014). One proposed mechanism that can explain this result is the strong tendency of PBDEs to remain in/on the microplastics rather than being taken up into amphipod tissue. Consequently, such interactions may also reduce the bioavailability of sorbed TrOCs in organisms (Gouin et al. 20II; Hirai et al. 20II). While this study demonstrated the reduced contribution of hydrophobic TrOCs associated with microplastics to the organism's health compared to the direct exposure pathway, it is thought that microplastics still act as a carrier of TrOCs to organism's tissue (Chua et al. 2014).

Thus, it appears that the influence of microplastics on the bioavailability of contaminants and their potential to act as a vector of contaminants to organisms, as well as the degree to which the sorbed contaminants pose a risk, may vary between different types of microplastics, contaminants and organisms (Koelmans et al. 20I3). Further, the potential of sorbed contaminants to migrate from microplastics to the organism tissue can be influenced by factors including the kinetics of TrOC desorption between plastic and tissues and the residence time of contaminated microplastics in the organism's body (Andrady 20II; Chua et al. 2014). There is evidence that the desorption and incorporation of TrOCs from microplastics to the organism's tissue can be facilitated by the organism's digestive fluid through desorbing sorbed TrOCs on contaminated microplastics, which may be enhanced by increasing the retention time of microplastics in the digestive tract (Bakir et al. 20I4; Chua et al. 20I4).

The risks associated with microplastics may also come from the chemicals embedded into the plastic polymer during manufacture, particularly if the components are not stable and can leach into the organism's body after ingestion. The biological effects of some additives, including phthalates, bisphenol A, alkylphenols and PBDEs, on different wildlife species has been widely reported (Foster 2006; Richter et al. 2007; Oehlmann et al. 2009; Jarmołowicz et al. 20I3). The concerns regarding leaching of plastic additives in aquatic organisms is associated with microplastics derived from the breakdown of larger plastic objects in the environment, but there is limited experimental data regarding adverse biological effects from additives incorporated in wastewater-based microplastics, such as microbeads and fibres. For example, inclusion of PBDEs as flame retardant in textiles and clothing is reported extensively (Rahman et al. 200I; Frederiksen et al. 2009). Brominated and chlorinated phthalocyanines are other fire retardant additives 
that can be introduced to enhance the thermal stability of fabric (Gladunova et al. 20I3), and can be toxic to marine organisms (Carmen \& Daniela 20I2). However, the leaching rate of the above contaminants from wastewater-based microfibers, as well as potential risks for the variety of aquatic organisms, is still unexplored.

\section{CONCLUSIONS AND FUTURE AREA OF RESEARCH}

The concerns regarding microplastics in WWTP effluent has rapidly increased in the last few years and preliminary research has confirmed wastewater as a source of microplastics in the receiving environment, with the amount contributed depending on the level of wastewater treatment. Due to the fact that even advanced treatment technologies cannot always remove $100 \%$ of microplastics (Schneiderman 20I5; Talvitie et al. 20I5), preventing the release of microplastics to wastewater influent would be the best action to reduce the discharge of wastewater-based microplastics to the aquatic environment. While preventive measures have been taken to remove some microplastic beads from the personal care products, this is more challenging for other sources of microplastics, particularly as synthetic clothing is also expected to be an important source of microfibres in wastewater. Consequently, further research on developing a sound mitigation strategy to prevent release to the environment would be beneficial.

This review has identified that there are still research gaps in this recently developing field of research, specifically: (i) to investigate the contribution of wastewater discharge from WWTPs to microplastics in the aquatic environments compared to other potential sources, (ii) to understand the behaviour of microplastics in WWTPs, and their physical and chemical modifications through wastewater treatment processes, and (iii) to understand the impact of sorption to microplastics on contaminant fate and toxicity in a more complex mixture that resemble wastewater. This research is necessary to better understand the relative contribution and significance of wastewater-based microplastics.

Since some wastewater-based microplastics from WWTPs can be transported from the discharged area and dispersed widely in the aquatic environment, collaborations at regional and global levels are required to establish management frameworks in terms of the maximum levels of microplastics in the wastewater effluent and to reduce the use of treated sewage sludge or biosolids with high concentrations of microplastics.

\section{ACKNOWLEDGEMENTS}

Shima Ziajahromi is supported by a Griffith University International Postgraduate Scholarship.

\section{REFERENCES}

Abril, G., Nogueira, M., Etcheber, H., Cabeçadas, G., Lemaire, E. \& Brogueira, M. J. 2002 Behaviour of organic carbon in nine contrasting European estuaries. Estuarine, Coastal and Shelf Science 54 (2), 241-262.

Andrady, A. L. 20II Microplastics in the marine environment. Mar. Pollut. Bull. 62 (8), 1596-1605.

Antunes, J. C., Frias, J. G. L., Micaelo, A. C. \& Sobral, P. 2013 Resin pellets from beaches of the Portuguese coast and adsorbed persistent organic pollutants. Estuarine, Coastal and Shelf Science 130, 62-69.

Ashton, K., Holmes, L. \& Turner, A. 20I0 Association of metals with plastic production pellets in the marine environment. Mar. Pollut. Bull. 60, 2050-2055.

Avio, C. G., Gorbi, S., Milan, M., Benedetti, M., Fattorini, D., d'Errico, G., Pauletto, M., Bargelloni, L. \& Regoli, F. 2015 Pollutants bioavailability and toxicological risk from microplastics to marine mussels. Environ. Pollut. 198, 211-222.

Bakir, A., Rowland, S. J. \& Thompson, R. C. 2012 Competitive sorption of persistent organic pollutants onto microplastics in the marine environment. Mar. Pollut. Bull. 64 (12), 2782-2789.

Bakir, A., Rowland, S. J. \& Thompson, R. C. 20I4 Enhanced desorption of persistent organic pollutants from microplastics under simulated physiological conditions. Environ. Pollut. 185, 16-23.

Beat the Microbeads 2015 Products that contain microplastic (UK). http://www.beatthemicrobead.org/images/pdf/redUK.pdf (accessed November 2015).

Brandsma, S. H., Nijssen, P., van Velzen, M. J. M. \& Leslie, H. A. 2014 Microplastics in river suspended particulate matter and sewage treatment plants. http://www.kenniswijzerzwerfafval. nl/download_document/571 (accessed August 2015).

Browne, M. A., Galloway, T. \& Thompson, R. 2007 Microplastican emerging contaminant of potential concern? Integr. Environ. Assess. Manage. 3, 560-561.

Browne, M. A., Dissanayake, A., Galloway, T. S., Lowe, D. \& Thompson, R. 2008 Ingested microscopic plastic translocates to the circulatory system of the mussel, Mytilus edulis (L.). Environ. Sci. Technol. 42, 5026-5031.

Browne, M. A., Crump, P., Niven, S. J., Teuten, E., Tonkin, A., Galloway, A. \& Thompson, R. 20II Accumulation of microplastics on shorelines worldwide: sources and sinks. Environ. Sci. Technol. 45, 9175-9179.

Browne, M. A., Niven, S. J., Galloway, T. S., Rowland, S. J. \& Thompson, R. C. 2013 Microplastic moves pollutants and additives to worms, reducing functions linked to health and biodiversity. Curr. Biol. 23 (23), 2388-2392. 
Carlos de Sa, L., Luis, L. G. \& Guilhermino, L. 2015 Effects of microplastics on juveniles of the common goby (Pomatoschistus microps): confusion with prey, reduction of the predatory performance and efficiency, and possible influence of developmental conditions. Environ. Pollut. 196, 359-362.

Carmen, Z. \& Daniela, S. 20ı2 Textile organic dyescharacteristics, polluting effects and separation/elimination procedures from industrial effluents- a critical overview. In: Organic Pollutants Ten Years After the Stockholm Convention Environmental and Analytical Update (Tomasz Puzyn \& A. Mostrag-Szlichtyng, eds), InTech, pp. 55-86.

Carr, S. A., Liu, J. \& Tesoro, A. G. 2016 Transport and fate of microplastic particles in wastewater treatment plants. Water Res. 91, 174-182.

Castañeda, R. A., Avlijas, S., Simard, M. A., Ricciardi, A. \& Smith, R. 2014 Microplastic pollution in St. Lawrence River sediments. Can. J. Fish. Aquat. Sci. 71 (12), 1767-1771.

Chua, E. M., Shimeta, J., Nugegoda, D., Morrison, P. D. \& Clarke, B. O. 2014 Assimilation of polybrominated diphenyl ethers from microplastics by the marine amphipod, Allorchestes compressa. Environ. Sci. Technol. 48, 8127-8134.

Claessens, M., De Meester, S., Van Landuyt, L., De Clerck, K. \& Janssen, C. R. 20II Occurrence and distribution of microplastics in marine sediments along the Belgian coast. Mar. Pollut. Bull. 62 (10), 2199-2204.

Cole, M., Lindeque, P., Halsband, C. \& Galloway, T. S. 20II Microplastics as contaminants in the marine environment: a review. Mar. Pollut. Bull. 62 (12), 2588-2597.

Cole, M., Lindeque, P., Fileman, E., Halsband, C. \& Galloway, T. S. 2015 The impact of polystyrene microplastics on feeding, function and fecundity in the marine copepod Calanus helgolandicus. Environ. Sci. Technol. 49 (2), 1130-1137.

Congress.gov. 20I5 Microbead-Free Water Act of 2015. http:// www.congress.gov/bill/114th-congress/house-bill/1321 (accessed March 2016).

Crawford, R. J. 1998 Plastics Engineering, Oxford; Boston.

da Costa, J. P., Santos, P. S., Duarte, A. C. \& Rocha-Santos, T. 2016 (Nano)plastics in the environment - sources, fates and effects. Sci. Total Environ. 566-567, 15-26.

Davarpanah, E. \& Guilhermino, L. 20I5 Single and combined effects of microplastics and copper on the population growth of the marine microalgae Tetraselmis chuii. Estuarine, Coastal and Shelf Science 167, 269-275.

Driedger, A. G. J., Dürr, H. H., Mitchell, K. \& Van Cappellen, P. 2015 Plastic debris in the Laurentian Great Lakes: a review. J. Great Lakes Res. 41 (1), 9-19.

Dris, R., Gasperi, J., Rocher, V., Saad, M., Renault, N. \& Tassin, B. 20I5a Microplastic contamination in an urban area: a case study in Greater Paris. Environ. Chem. 15 (2), 592-599.

Dris, R., Gasperi, J., Rocher, V., Saad, M., Renault, N. \& Tassin, B. 20I5b Microplastic contamination in an urban area: a case study in Greater Paris. Environ. Chem. 12 (5), 592.

Dris, R., Imhof, H., Sanchez, W., Gasperi, J., Galgani, F., Tassin, B. \& Laforsch, C. 2015c Beyond the ocean: contamination of freshwater ecosystems with (micro-) plastic particles. Environ. Chem. 12, 539-550.
Duis, K. \& Coors, A. 2016 Microplastics in the aquatic and terrestrial environment: sources (with a specific focus on personal care products), fate and effects. Environ. Sci. Eur. 28 (1), 1-25.

Eerkes-Medrano, D., Thompson, R. C. \& Aldridge, D. C. 2015 Microplastics in freshwater systems: a review of the emerging threats, identification of knowledge gaps and prioritisation of research needs. Water Res. 75, 63-82.

Eisler, R. 2000 Hand Book of Chemical Risk Assessment, Health Hazards to Humans, Plants, and Animals. Lewis.

Eriksen, M., Mason, S., Wilson, S., Box, C., Zellers, A., Edwards, W., Farley, H. \& Amato, S. 2orza Microplastic pollution in the surface waters of the Laurentian Great Lakes. Mar. Pollut. Bull. 77 (1-2), 177-182.

Eriksen, M., Maximenko, N., Thiel, M., Cummins, A., Lattin, G., Wilson, S., Hafner, J., Zellers, A. \& Rifman, S. 2orzb Plastic pollution in the South Pacific subtropical gyre. Mar. Pollut. Bull. 68 (1-2), 71-76.

Fendall, L. S. \& Sewell, M. A. 2009 Contributing to marine pollution by washing your face: microplastics in facial cleansers. Mar. Pollut. Bull. 58, 1225-1228.

Foster, P. M. 2006 Disruption of reproductive development in male rat offspring following in utero exposure to phthalate esters. Int. J. Androl. 29 (1), 140-147.

Fotopoulou, K. N. \& Karapanagioti, H. K. 2012 Surface properties of beached plastic pellets. Mar. Environ. Res. 81, 70-77.

Frederiksen, M., Vorkamp, K., Thomsen, M. \& Knudsen, L. E. 2009 Human internal and external exposure to PBDEs-a review of levels and sources. Int. J. Hyg. Environ. Health 212 (2), 109-134.

Free, C. M., Jensen, O. P., Mason, S. A., Eriksen, M., Williamson, N. J. \& Boldgiv, B. 20I4 High-levels of microplastic pollution in a large, remote, mountain lake. Mar. Pollut. Bull. 85 (1), 156-163.

Frias, J. P., Sobral, P. \& Ferreira, A. M. 2oro Organic pollutants in microplastics from two beaches of the Portuguese coast. Mar. Pollut. Bull. 60 (11), 1988-1992.

Galgani, F., Fleet, D., Van Franeker, J., Katsanevakis, S., Maes, T., Mouat, J., Oosterbaan, L., Poitou, I., Hanke, G., Thompson, R. C., Amato, Birkun A. \& Janssen, C. 2oro Marine Strategy Framework Directive Task Group 10 Report Marine Litter. union European Union, Luxembourg.

Gallagher, A., Rees, A., Rowe, R., Stevens, J. \& Wright, P. 2015 Microplastics in the Solent estuarine complex, UK: an initial assessment. Mar. Pollut. Bull.

Ghaly, A. E., Ananthashankar, A., Alhattab, M. \& Ramakrishnan, V. 2013 Production, characterization and treatment of textile effluents: a critical review. J. Chem. Eng. Process. Technol. 5 (1), 182.

Gladunova, O. I., Lysenko, V. A., Astashkina, O. V., Lysenko, A. A. \& Dokuchaev, V. N. 2013 Polyoxadiazole fibers modified by nano-additives. Russ. J. Phys. Chem. A 83 (1), 164-168.

Gouin, T., Roche, N., Lohmann, R. \& Hodges, G. 20 II A thermodynamic approach for assessing the environmental exposure of chemicals absorbed to microplastic. Environ. Sci. Technol. 45 (4), 1466-1472.

Gouin, T., Avalos, J., Brunning, I., Brzuska, K., de Graaf, J., Kaumanns, J., Koning, J., Meyberg, M., Rettinger, K., 
Schlatter, H., Thomas, J., van Welie, R. \& Wolf, T. 2015 Use of micro-plastic beads in cosmetic products in Europe and their estimated emissions to the North Sea environment. SOFWJournal 40-46.

Hamer, J., Gutow, L., Kohler, A. \& Saborowski, R. 2014 Fate of microplastics in the marine isopod Idotea emarginata. Environ. Sci. Technol. 48 (22), 13451-13458.

Hammer, M. J. 2008 Water and Wastewater Technology. Pearson.

Hammer, J., Kraak, M. H. \& Parsons, J. R. 20I2 Plastics in the marine environment: the dark side of a modern gift. Rev. Environ. Contam. Toxicol. 220, 1-44.

HELCOM 2014 BASE project 2012-2014: Preliminary Study on Synthetic Microfibers and Particles at a Municipal Waste Water Treatment Plant.

Hirai, H., Takada, H., Ogata, Y., Yamashita, R., Mizukawa, K., Saha, M., Kwan, C., Moore, C., Gray, H., Laursen, D., Zettler, E. R., Farrington, J. W., Reddy, C. M., Peacock, E. E. \& Ward, M. W. 2oII Organic micropollutants in marine plastics debris from the open ocean and remote and urban beaches. Mar. Pollut. Bull. 62 (8), 1683-1692.

Holmes, L. A., Turner, A. \& Thompson, R. C. 2012 Adsorption of trace metals to plastic resin pellets in the marine environment. Environ. Pollut. 160 (1), 42-48.

Holmes, L. A., Turner, A. \& Thompson, R. C. 2014 Interactions between trace metals and plastic production pellets under estuarine conditions. Mar. Chem. 167, 25-32.

Huang, X., Teng, X., Chen, D., Tang, F. \& He, J. 2010 The effect of the shape of mesoporous silica nanoparticles on cellular uptake and cell function. Biomaterials 31 (3), 438-448.

Ivar do Sul, J. A. \& Costa, M. F. 2014 The present and future of microplastic pollution in the marine environment. Environ. Pollut. 185, 352-364.

Ivar do Sul, J. A., Costa, M. F. \& Fillmann, G. 20I4 Microplastics in the pelagic environment around oceanic islands of the western tropical Atlantic Ocean. Water Air Soil Pollut. 225 (7), 2004.

Jambeck, J. R., Geyer, R., Wilcox, C., Siegler, T. R., Perryman, M., Andrady, A., Narayan, R. \& Law, K. L. 2015 Marine pollution. Plastic waste inputs from land into the ocean. Science $\mathbf{3 4 7}$ (6223), 768-771.

Jarmołowicz, S., Demska-Zakęś, K. \& Zakęś, Z. 2013 Impact of din-butyl phthalate on reproductive system development in European pikeperch (Sander lucioperca). Acta Veterinaria Brno 82 (2), 197-201.

Karapanagioti, H. K., Endo, S., Ogata, Y. \& Takada, H. $201 \mathrm{I}$ Diffuse pollution by persistent organic pollutants as measured in plastic pellets sampled from various beaches in Greece. Mar. Pollut. Bull. 62 (2), 312-317.

Klein, S., Worch, E. \& Knepper, T. P. 2015 Occurrence and spatial distribution of microplastics in river shore sediments of the Rhine-Main Area in Germany. Environ. Sci. Technol. 49 (10), 6070-6076.

Koelmans, A. A., Besseling, E., Wegner, A. \& Foekema, E. M. 2013 Plastic as a carrier of pops to aquatic organisms: a model analysis. Environ. Sci. Technol. 47 (14), 7812-7820.

Koelmans, A. A., Gouin, T., Thompson, R., Wallace, N. \& Arthur, C. 2014 Plastics in the marine environment. Environ. Toxicol. Chem. 33 (1), 5-10.
Law, K. L. \& Thompson, R. C. 2014 Microplastics in the seas. Science 345 (6193), 144-145.

Law, K. L., Moret-Ferguson, S., Maximenko, N. A., Proskurowski, G., Peacock, E. E., Hafner, J. \& Reddy, C. M. 2oro Plastic accumulation in the North Atlantic subtropical gyre. Science 329 (5996), 1185-1188.

Lee, K. W., Shim, W. J., Kwon, O. Y. \& Kang, J. H. 2013 Sizedependent effects of micro polystyrene particles in the marine copepod Tigriopus japonicus. Environ. Sci. Technol. 47 (19), 11278-11283.

Leslie, H. A. 2014 Review of Microplastics in Cosmetics. IVM Institute for Environmental Studies. No. R1 14/29.

Lobelle, D. \& Cunliffe, M. 20II Early microbial biofilm formation on marine plastic debris. Mar. Pollut. Bull. 62 (1), 197-200.

Luis, L. G., Ferreira, P., Fonte, E., Oliveira, M. \& Guilhermino, L. 2015 Does the presence of microplastics influence the acute toxicity of chromium(VI) to early juveniles of the common goby (Pomatoschistus microps)? A study with juveniles from two wild estuarine populations. Aquat. Toxicol. 164, 163-174.

Ma, R. \& Shih, K. 2оIo Perfluorochemicals in wastewater treatment plants and sediments in Hong Kong. Environ. Pollut. 158 (5), 1354-1362.

Magnusson, K. \& Norén, F. 2014 Screening of microplastic particles in and down-stream a wastewater treatment plant, IVL Swedish Environmental Research Institute. No. C55.

Mato, Y., Isobe, T., Takada, H., Kanehiro, H., Ohtake, C. \& Kaminuma, T. 200I Plastic resin pellets as a transport medium for toxic chemicals in the marine environment. Environ. Sci. Technol. 35, 318-324.

Matsuzawa, Y. 20Io Removal of hydrophobic organic contaminants from aqueous solutions by sorption onto biodegradable polyesters. J. Water. Resource. Prot. 02 (03), 214-221.

McCormick, A., Hoellein, T. J., Mason, S. A., Schluep, J. \& Kelly, J. J. 2014 Microplastic is an abundant and distinct microbial habitat in an urban river. Environ. Sci. Technol. 48 (20), 11863-11871.

Mizukawa, K., Takada, H., Ito, M., Geok, Y. B., Hosoda, J., Yamashita, R., Saha, M., Suzuki, S., Miguez, C., Frias, J., Antunes, J. C., Sobral, P., Santos, I., Micaelo, C. \& Ferreira, A. M. 2013 Monitoring of a wide range of organic micropollutants on the Portuguese coast using plastic resin pellets. Mar. Pollut. Bull. 70 (1-2), 296-302.

Murphy, F., Ewins, C., Carbonnier, F. \& Quinn, B. 2016 Wastewater treatment works (WWTW) as a source of microplastics in the aquatic environment. Environ. Sci. Technol. 50 (11), 5800-5808.

Nakashima, E., Isobe, A., Kako, S., Itai, T. \& Takahashi, S. 2012 Quantification of toxic metals derived from macroplastic litter on Ookushi Beach, Japan. Environ. Sci. Technol. 46 (18), 10099-10105.

Napper, I. E., Bakir, A., Rowland, S. J. \& Thompson, R. C. 2015 Characterisation, quantity and sorptive properties of microplastics extracted from cosmetics. Mar. Pollut. Bull. 99 (1-2), 178-185.

Oehlmann, J., Schulte-Oehlmann, U., Kloas, W., Jagnytsch, O., Lutz, I., Kusk, K. O., Wollenberger, L., Santos, E. M., Paull, G. C., Van Look, K. J. \& Tyler, C. R. 2009 A critical analysis 
of the biological impacts of plasticizers on wildlife. Philos. Trans. R. Soc. London B. Biol. Sci. 364 (1526), 2047-2062.

Pan, B. \& Xing, B. 2008 Adsorption mechanisms of organic chemicals on carbon nanotubes. Environ. Sci. Technol. 42 (24), 9005-9013.

Peda, C., Caccamo, L., Fossi, M. C., Gai, F., Andaloro, F., Genovese, L., Perdichizzi, A., Romeo, T. \& Maricchiolo, G. 2016 Intestinal alterations in European sea bass Dicentrarchus labrax (Linnaeus, 1758) exposed to microplastics: preliminary results. Environ. Pollut. 212, 251-256.

Rahman, F., Langford, K. H., Scrimshaw, M. D. \& Lester, J. N. 200I Polybrominated diphenyl ether (PBDE) flame retardants. Sci. Total Environ. 275 (1-3), 1-17.

Richter, C. A., Birnbaum, L. S., Farabollini, F., Newbold, R. R., Rubin, B. S., Talsness, C. E., Vandenbergh, J. G., Walser-Kuntz, D. R. \& vom Saal, F. S. 2007 In vivo effects of bisphenol A in laboratory rodent studies. Reprod. Toxicol. 24 (2), 199-224.

Rillig, M. C. 2012 Microplastic in terrestrial ecosystems and the soil? Environ. Sci. Technol. 46 (12), 6453-6454.

Rios, L. M., Jones, P. R., Mooreb, C. \& Narayana, U. V. 2010 Quantitation of persistent organic pollutants adsorbed on plastic debris from the Northern Pacific Gyre's 'eastern garbage patch'. J. Environ. Monitor. 12, 2226-2236.

Rocha-Santos, T. \& Duarte, A. C. 2015 A critical overview of the analytical approaches to the occurrence, the fate and the behavior of microplastics in the environment. TrAC-Trend. Anal. Chem. 65, 47-53.

Rochman, C. M. 2015 The complex mixture, fate and toxicity of chemicals associated with plastic debris in the marine environment. In: Marine Anthropogenic Litter (M. Bergmann, L. Gutow \& M. Klages, eds). Springer, pp. 117-140.

Rochman, C. M., Hoh, E., Hentschel, B. T. \& Kaye, S. 2orza Longterm field measurement of sorption of organic contaminants to five types of plastic pellets: implications for plastic marine debris. Environ. Sci. Technol. 47 (3), 1646-1654.

Rochman, C. M., Hoh, E., Kurobe, T. \& Teh, S. J. 2oIzb Ingested plastic transfers hazardous chemicals to fish and induces hepatic stress. Sci. Rep. 3, 3263.

Rochman, C. M., Hentschel, B. T. \& Teh, S. J. 2014 Long-term sorption of metals is similar among plastic types: implications for plastic debris in aquatic environments. PLoS One 9 (1), e85433.

Rochman, C. M., Kross, S. M., Armstrong, J. B., Bogan, M. T., Darling, E. S., Green, S. J., Smyth, A. R. \& Verissimo, D. 2015 Scientific evidence supports a ban on microbeads. Environ. Sci. Technol. 49, 10759-10761.

Schneiderman, E. T. 2015 Discharging Microbeads to Our Waters: An Examination of Wastewater Treatment Plants in New York. http://www.ag.ny.gov/pdfs/2015_Microbeads_Report_FINAL. pdf (accessed August 2015).

Smedes, F., Geertsma, R. W., van der Zande, T. \& Booij, K. 2009 Polymer-water partition coefficients of hydrophobic compounds for passive sampling: application of cosolvent models for validation. Environ. Sci. Technol. 43 (18), 7047-7054.

Stephenson, T. \& Stuetz, R. 2009 Principles of Water and Wastewater Treatment Processes. IWA Publishing, London, UK.

Storm Water Solution 2013 Storm Water Solution, Chicago Selects UV Wastewater Treatment Solution. http://www.estormwater.com/chicago-selects-uvwastewater-treatment-solution (accessed June 2015).

Syberg, K., Khan, F. R., Selck, H., Palmqvist, A., Banta, G. T., Daley, J., Sano, L. \& Duhaime, M. B. 2015 Microplastics: addressing ecological risk through lessons learned. Environ. Toxicol. Chem. 34, 945-953.

Talvitie, J., Heinonen, M., Paakkonen, J. P., Vahtera, E., Mikola, A., Setala, O. \& Vahala, R. 2015 Do wastewater treatment plants act as a potential point source of microplastics? Preliminary study in the coastal Gulf of Finland, Baltic Sea. Water Sci. Technol. 72 (9), 1495-1504.

Teuten, E. L., Rowland, S. J., Galloway, T. S. \& Thompson, R. C. 2007 Potential for plastics to transport hydrophobic contaminants. Environ. Sci. Technol. 41, 7759-7764.

Teuten, E. L., Saquing, J. M., Knappe, D. R., Barlaz, M. A., Jonsson, S., Bjorn, A., Rowland, S. J., Thompson, R. C., Galloway, T. S., Yamashita, R., Ochi, D., Watanuki, Y., Moore, C., Viet, P. H., Tana, T. S., Prudente, M., Boonyatumanond, R., Zakaria, M. P., Akkhavong, K., Ogata, Y., Hirai, H., Iwasa, S., Mizukawa, K., Hagino, Y., Imamura, A., Saha, M. \& Takada, H. 2009 Transport and release of chemicals from plastics to the environment and to wildlife. Philos. Trans. R. Soc. London B. Biol. Sci. 364, 2027-2045.

Ukiwe, L. N., Ibeneme, S. I., Duru, C. E., Okolue, B. N., Onyedika, G. O. \& Nweze, C. A. 2014 Chemical and electrocoagulation techniques in coagulation-flocculation in water and wastewater treatment- a review. IJRRAS 18, 285-294.

UNEP 2010 (United Nations Environment Programme), Sick Water? The central role of wastewater management in sustainable development. United Nations Environment Programme and UN-HABITAT G-A, Norway.

Vodokanal 2015 Vodokanal of St. Petersburg. http://www. vodokanal.spb.ru/en/kanalizovanie/struktura_ kanalizovaniya/ (Accessed November 2015).

von Moos, N., Burkhardt-Holm, P. \& Kohler, A. 2012 Uptake and effects of microplastics on cells and tissue of the blue mussel Mytilus edulis, L. after an experimental exposure. Environ. Sci. Technol. 46, 11327-11335.

Wagner, M., Scherer, C., Alvarez-Muñoz, D., Brennholt, N., Bourrain, X., Buchinger, S., Fries, E., Grosbois, C., Klasmeier, J., Marti, T., Rodriguez-Mozaz, S., Urbatzka, R., Vethaak, A., Winther-Nielsen, M. \& Reifferscheid, G. 2014 Microplastics in freshwater ecosystems: what we know and what we need to know. Environ. Sci. Eur. 26 (1), 12.

Wang, F., Shih, K. M. \& Li, X. Y. 2015 The partition behavior of perfluorooctanesulfonate (PFOS) and perfluorooctanesulfonamide (FOSA) on microplastics. Chemosphere 119, 841-847.

Woodall, L. C., Sanchez-Vidal, A., Canals, M., Paterson, G. L. J., Coppock, R., Sleight, V., Calafat, A., Rogers, A. D., Narayanaswamy, B. E. \& Thompson, R. C. 2014 The deep sea is a major sink for microplastic debris. R. Soc. Open. Sci. 1 (4), 140317.

Wright, S. L., Rowe, D., Thompson, R. C. \& Galloway, T. S. 2orza Microplastic ingestion decreases energy reserves in marine worms. Curr. Biol. 23 (23), 1031-1033. 
Wright, S. L., Thompson, R. C. \& Galloway, T. S. 20Izb The physical impacts of microplastics on marine organisms: a review. Environ. Pollut. 178, 483-492.

Zarfl, C. \& Matthies, M. 2oIo Are marine plastic particles transport vectors for organic pollutants to the Arctic? Mar. Pollut. Bull. 60 (10), 1810-1814.
Zhao, S., Zhu, L., Wang, T. \& Li, D. 2014 Suspended microplastics in the surface water of the Yangtze estuary system, China: first observations on occurrence, distribution. Mar. Pollut. Bull. 86 (1-2), 562-568.

Zitko, V. \& Hanlon, M. I99I Another source of pollution by plastics - skin cleaners with plastic scrubbers. Mar. Pollut. Bull. 22, 41-42.

First received 27 April 2016; accepted in revised form 18 August 2016. Available online 2 September 2016 